\title{
UPAYA MENINGKATKAN HASIL BELAJAR PAI SISWA V SD NEGERI 003 TASIK JUANG MELALUI MODEL PEMBELAJARAN GROUP INVESTIGATION
}

\author{
Teni \\ teni70@gmail.com \\ SD Negeri 003 Tasik Juang, Indragiri Hulu, Indonesia
}

\begin{abstract}
This study aims to improve student learning outcomes of PAI through the Group Investigation learning model. This research is a classroom action research conducted at SDN 003 Tasik Juang. The subjects of this study were 30 people. The research will be carried out from August to September 2019. The research instrument used was an observation sheet and a test of learning outcomes. The results showed an increase in student learning activities and outcomes with a percentage of student activities in the first cycle of $57.5 \%$ with enough categories increased to $72.5 \%$ with a high category, student learning outcomes in the first cycle showed as many as 17 students or 56.7\% who meet the KKM value set with an average learning outcome of 64.5 which is included in the category of being increased in the second cycle which shows as many as 24 students or $80 \%$ have met the KKM with an average of 75.3 which is included in the high category. Based on these results it can be concluded that the learning model of Group Investigation can improve the learning outcomes of PAI SDN 003 Tasik Juang students.
\end{abstract}

Keywords: learning outcomes, group investigation learning model

\begin{abstract}
ABSTRAK
Penelitian ini bertujuan untuk meningkatkan hasil belajar PAI siswa melalui model pembelajaran Group Investigation. Penelitian ini merupakan penelitian tindakan kelas yang dilaksanakan pada SD Negeri 003 Tasik Juang. Subjek penelitian ini berjumlah 30 orang. Pelaksanaan penelitian ini dimulai dari bulan Agustus sampai September 2019. Instrumen penelitian yang digunakan adalah lembar observasi dan tes hasil belajar. Hasil penelitian menunjukkan terjadi peningkatan aktivitas dan hasil belajar siswa dengan persentase aktivitas siswa siklus I sebesar 57,5\% dengan kategori cukup meningkat menjadi 72,5\% dengan kategori tinggi, hasil belajar siswa pada siklus I menunjukkan sebanyak 17 siswa atau 56,7\% yang memenuhi nilai KKM yang ditetapkan dengan rata-rata hasil belajar sebesar 64,5 yang termasuk kategori sedang mengalami peningkatan pada siklus II yang menunjukkan sebanyak 24 siswa atau 80\% telah memenuhi KKM dengan rata-rata 75,3 yang termasuk kategori tinggi. Berdasarkan hasil tersebut dapat disimpulkan bahwa model pembelajaran Group Investigation dapat meingkatkan hasil belajar PAI siswa SD Negeri 003 Tasik Juang.
\end{abstract}

Kata Kunci: hasil belajar, model pembelajaran group investigation

\begin{tabular}{|c|c|c|}
\hline Submitted & Accepted & Published \\
\hline 23 Juni 2019 & 20 Oktober 2019 & 14 November 2019 \\
\hline
\end{tabular}

\begin{tabular}{|l|c|c|c|c|}
\hline Citation & $:$ & $\begin{array}{c}\text { Teni. (2019). Upaya Meningkatkan Hasil Belajar PAI Siswa V SD Negeri 003 Tasik Juang Melalui Model Pembelajaran } \\
\text { Group Investigation. Jurnal PAJAR (Pendidikan dan Pengajaran), 3(6), 1366-1374. DOI : } \\
\text { http://dx.doi.org/10.33578/pjr.v3i6.7900. }\end{array}$ \\
\hline
\end{tabular}

\section{PENDAHULUAN}

Pendidikan

$$
\text { bertujuan }
$$

untuk mencerdaskan manusia dan memiliki karakter yang baik. Pendidikan dalam agama Islam memiliki landasan yang jelas bagi seluruh manusia melalui syariat Islam yang tercantum dalam Alquran. Semua ilmu ada dalam Alquran, hanya saja sejauh mana seseorang mau dan mampu mempelajari dan memahami kandungan di dalamnya. Untuk mencapai tingkatan mampu memahami isi kandungan Al-Qur'an tentu terlebih dahulu seseorang mampu membacanya dengan baik dan benar sesuai hukum.
Satu tujuan pembelajaran di sekolah adalah untuk meningkatkan hasil belajar siswa, kemampuan itu dapat terpenuhi melalui pembelajaran yang baik. Guru harus mampu merencanakan, menyiapkan, mengolah, dan menganalisis setiap proses agar pembelajaran menjadi kondusif dan menyenangkan sehingga tujuan pembelajaran dapat tercapai (Hasnawati, 2019). Selain itu peran guru sangat penting dan menentukan dalam meningkatkan kualitas pendidikan (Asrawati, 2019). 
Berdasarkan undang-undang sistem pendidikan nasional nomor 20 tahun 2003, bahwa pendidikan merupakan usaha sadar dan terencana untuk mewujudkan suasana belajar dan proses pembelajaran agar siswa secara aktif mengembangkan potensi dirinya untuk memiliki kekuatan spiritual keagamaan, pengendalian diri, kepribadian, kecerdasan, akhlak mulia, serta keterampilan yang diperlukan dirinya, masyarakat, bangsa dan negara. Oleh karena itu, guru harus terlibat langsung pada proses pembelajaran sehingga guru bisa mengembangkan potensi siswa secara menyeluruh pada setiap mata pelajaran yang diajarkannya. Oleh sebab itu guru dituntut harus memiliki kemampuan untuk memilih dan menggunakan metode yang tepat dalam meningkatkan aktivitas dan hasil belajar siswa (Rosdianah, 2019).

Melihat fakta di lapangan, masih banyak kendala yang ditemukan perihal akivitas di kelas dan hasil belajar siswa. Guru masih menggunakan metode pembelajaran yang tidak variatif sehingga proses pembelajaran kurang menyenangkan yang menyebabkan hasil belajar siswa masih rendah. Berdasarkan UH, hasil yang diperoleh siswa di bawah kriteria ketuntasan minimum (KKM) dari 30 siswa hanya 17 orang yang mencapai KKM dengan persentase 56,7\%,

\section{KAJIAN TEORETIS}

Salah satu model pembelajaran kooperatif yang mampu meningkatkan aktifitas siswa dan memperbaiki proses dan hasil belajar siswa adalah model pembelajaran group investigation, dimana model pembelajaran ini membantu siswa untuk melakukan investigasi terhadap suatu topik secara sistematis dan analitik. Hal ini mempunyai implikasi yang positif terhadap pengembangan keterampilan penemuan dan membantu mencapai tujuan (Suroyya \& Rochmat, 2015). Lebih lanjut Dasinah (2019) mengemukakan bahwa model kooperatif tipe GI melatih siswa untuk memiliki kemampuan yang baik dalam berkomunikasi dan mengemukakan pendapatnya. Memotivasi dan mendorong siswa agar aktif dalam proses belajar mulai dari tahap pertama sampai tahap akhir pembelajaran. Merujuk pada pendapat ahli, dapat sedangkan yang tidak mencapai KKM sebanyak 13 orang dengan persentase $43.3 \%$ sementara KKM yang ditetapkan adalah sebesar $70 \%$ secara klasikal. Oleh karena itu diperlukan alternatif pembelajaran yang dapat mengatasi permasalahan yang dihadapi siswa.

Salah satu model pembelajaran yang diharapkan mampu meningkatkan hasil belajar siswa adalah model pembelajaran group investigation atau dikenal dengan singkatan GI. GI merupakan salah satu jenis model pembelajaran yang lebih memberikan kesempatan kepada siswa untuk mencari penyelesaian kasus dan guru hanya lebih berperan sebagai motivator. GI dalam pembelajaran dilakukan secara berkelompok, setiap anggota kelompok dibagi secara heterogen. Masing-masing kelompok dalam pembelajaran membahas topik atau permasalahan yang berbeda. Semua anggota kelompok harus turut andil dalam menentukan topik yang akan mereka ambil. Selama proses investigasi anggota kelompok akan terlibat dalam aktivitas-aktivitas berpikir tingkat tinggi, seperti membuat sintesis, ringkasan, hipotesis, kesimpulan dan menyajikan laporan akhir (Huda dalam Marhadi, 2016). Pada akhirnya, melalui penerapan model pembelajaran GI diharapkan dapat memperbaiki proses dan hasil belajar siswa.

penulis tarik kesimpulan bahwa model pembelajaran GI merupakan pembelajaran kooperatif yang memfasilitasi siswa untuk aktif bekerja sama dalam proses pembelajaran dalam merencanakan, melakukan penemuan/ investigasi, menganalisis, dan mengkomunikasikan hasil investigasi.

Pada model pembelajaran GI, guru menyiapkan terlebih dahulu masalah untuk sekelompok siswa pada jenjang kemampuan tertentu. Siswa menghadapi masalah yang kemudian diarahkan kepada menemukan konsep atau prinsip. Konsep atau prinsip tersebut tertanam dengan baik pada diri siswa yang pada akhirnya siswa menguasai konsep atau prinsip dan dapat mengaitkannya dengan kehidupan sehari- 
hari. Keterlibatan aktif siswa dalam proses pembelajaran dapat ditangani dengan baik.

Berdasarkan pendapat Slavin dalam Hosnan (2014), mengemukakan bahwa terdapat enam tahapan dalam pelaksanaan Model GI, yaitu: 1). mengidentifikasi topik dan mengatur siswa kedalam kelompok. 2). merencanakan tugas yang akan dipelajari, 3). melaksanakan investigasi, 4). menyiapkan laporan, 5). mempresentasikan laporan, dan 6). evaluasi. Lebih lanjut penjabaran dari setiap tahapan dapat dilihat pada tabel berikut (Dasinah, 2019):

\section{Tabel 1. Tahapan Pembelajaran Group Investigation}

\begin{tabular}{|c|c|}
\hline Tahapan & Kegiatan Pembelajaran \\
\hline $\begin{array}{c}\text { Fase } 1 \\
\text { Seleksi Topik }\end{array}$ & $\begin{array}{l}\text { Para siswa memilih berbagai subtopik dalam suatu wilayah masalah umum yang } \\
\text { biasanya digambarkan lebih dahulu oleh guru. Para siswa selanjutnya diorganisasikan } \\
\text { menjadi kelompok-kelompok yang berorientasi pada tugas (task oriented groups) } \\
\text { yang beranggotakan } 2 \text { hingga } 6 \text { orang. Komposisi kelompok heterogen,baik dalam } \\
\text { jenis kelamin etnik maupun kemampuan akademik. }\end{array}$ \\
\hline $\begin{array}{l}\text { Fase } 2 \\
\text { Merencanakan } \\
\text { Kerjasama }\end{array}$ & $\begin{array}{l}\text { Para siswa beserta guru merencanakan berbagai prosedur belajar khusus, tugas dan } \\
\text { tujuan umum yang konsisten dengan berbagai topik dan subtopik yang telah dipilih } \\
\text { dari langkah fase- } 1 \text { di atas. }\end{array}$ \\
\hline $\begin{array}{c}\text { Fase } 3 \\
\text { Implementasi }\end{array}$ & $\begin{array}{l}\text { Para siswa melaksanakan rencana yang telah dirumuskan pada langkah fase- } 2 \text {. } \\
\text { Pembelajaran harus melibatkan berbagai aktivitas dan keterampilan dengan variasi } \\
\text { yang luas dan mendorong para siswa untuk menggunakan berbagai sumber, baik } \\
\text { yang terdapat di dalam maupun di luar sekolah. Guru cara terus-menerus mengikuti } \\
\text { kemajuan tiap kelompok dan memberikan bantuan jika diperlukan. }\end{array}$ \\
\hline $\begin{array}{c}\text { Fase } 4 \\
\text { Analisis dan Sintesis }\end{array}$ & $\begin{array}{l}\text { Para siswa menganalisis dan menyintesis berbagai imformasi yang diperoleh pada } \\
\text { langkah fase- } 3 \text { dan merencanakan agar dapat diringkaskan dalam suatu penyajian } \\
\text { yang menarik di depan kelas. }\end{array}$ \\
\hline $\begin{array}{c}\text { Fase } 5 \\
\text { Penyajian Hasil Akhir }\end{array}$ & $\begin{array}{l}\text { Semua kelompok menyajikan suatu presentasi yang menarik dari berbagai topik yang } \\
\text { telah dipelajari agar semua siswa dalam kelas saling terlibat dan mencapai suatu } \\
\text { perspektif yang luas mengenai topik tersebut. Presentasi kelompok dikoordinir oleh } \\
\text { guru. }\end{array}$ \\
\hline $\begin{array}{c}\text { Fase } 6 \\
\text { Evaluasi }\end{array}$ & $\begin{array}{l}\text { Guru beserta siswa melakukan evaluasi mengenai kontribusi tiap kelompok terhadap } \\
\text { pekerjaan kelas sebagai suatu keseluruhan. Evaluasi dapat mencakup tiap siswa } \\
\text { secara individu atau kelompok, atau keduanya. }\end{array}$ \\
\hline
\end{tabular}

Siswa diberikan masalah berkaitan dengan materi yang dipelajari kemudian memilih subtopik yang akan dibahas dalam kelompok yang telah dibuat secara heterogen, kemudian siswa melakukan perencanaan kerjasama dan mengimplementasikannya secara berkelompok. Tugas masing-masing kelompok adalah melakukan analisis dan sintesis terhadap masalah yang dipilih. Setelah menghasilkan temuan maka masing-masing kelompok menyajikan hasil investigasi. Setiap sajian diberikan tanggapan dan dilakukan evaluasi jika ada yang perlu diperbaiki sehingga siswa secara bersama memahai konsep dengan baik berdasarkan temuan dan diskusi yang mereka lakukan sesuai bimbingan guru.

\section{METODE PENELITIAN}

Penelitian ini merupakan penelitian tindakan kelas (PTK) yang dilaksanakan di SD Negeri 003 Tasik Juang, dengan pertimbangan karena SD ini mau melakukan perubahan sekaligus tempat peneliti bertugas. Subjek penelitian ini adalah siswa kelas $\mathrm{V}$ yang

berjumlah 30 orang, terdiri dari 18 perempuan dan 12 laki-laki. Penelitian ini dilaksanakan selama 2 bulan mulai bulan awal Agustus sampai akhir September 2019.

Desain penelitian PTK merujuk pada Arikunto (2012) yang terdiri dari empat tahapan 
yaitu: 1) perencanaan (planning), 2) pelaksanaan (action), 3) pengamatan (observation), 4) refleksi (reflection). Konsep dasar PTK ini adalah mengetahui secara jelas masalah-masalah yang ada di kelas dan mengatasi masalah tersebut. Adapun masalah yang diteliti dalam penelitian ini adalah masalah pembelajaran terutama hasil belajar siswa.

Pengumpulan data terdiri dari data hasil observasi terhadap aktivitas siswa dan hasil belajar siswa. Instrumen penelitian menggunakan lembar observasi aktivitas siswa dan tes hasil belajar siswa. Analisis data yang digunakan adalah analisis deskriptif komparatif. Data kuantitatif yang diperoleh dideskripsikan dalam bentuk kata-kata atau penjelasan, baik data yang diperoleh dari hasil tes maupun keaktifan siswa. Selanjutnya dilakukan komparasi data setiap siklus untuk memastikan ada tidaknya peningkatan hasil belajar dan keaktifan siswa pada mata pelajaran PAI. Sebagai tolok ukur keberhasilan pelaksanaan tindakan kelas ini ditetapkan indikator sebagai berikut: 1) meningkatnya keaktifan siswa minimal sebesar $20 \%$ untuk setiap siklus. 2) Persentase jumlah siswa yang mencapai $\mathrm{KKM} \geq 70$ adalah sebesar $75 \%$ dari jumlah siswa yang dilakukan ujicoba yakni 30 orang. Aktifitas siswa dalam proses pembelajaran dapat diolah menggunakan rumus (Dasinash, 2019) berikut:

$\mathrm{NR}=\frac{J S}{S M} x 100 \%$

Keterangan:

NR : persentase rata-rata aktifitas siswa

JS : jumlah skor aktifitas yang dilakukan

SM : skor maksimal yang diperoleh dari aktivitas siswa

Aktivitas siswa yang diamati mulai dari tahapan pendahuluan, inti, dan penutup. Adapun kategori aktifitas siswa dikelompokkan dalam tabel berikut:

Tabel 2. Interval dan Kategori Aktifitas Siswa

\begin{tabular}{cc}
\hline Interval $(\%)$ & Kategori \\
\hline $81-100$ & Baik Sekali \\
$61-80$ & Baik \\
$51-60$ & Cukup \\
$\leq 50$ & Kurang \\
\hline
\end{tabular}

Purwanto (dalam Dasinah, 2019)

Adapun ketuntasan hasil belajar siswa untuk menghitung peningkatannya digunakan rumus berikut (Dasinah, 2019):

Ketuntasan individu $=\frac{\text { jumlah } \text { jawaban benar }}{\text { jumlah } \text { soal }} \times 100 \%$
Setelah didapat hasil belajar siswa, langkah selanjutnya adalah melakukan pengategorian hasil belajar siswa. Adapun kategori dari hasil belajar siswa dapat dilihat sebagai berikut

Tabel 3. Kategori Hasil Belajar Siswa

\begin{tabular}{cc}
\hline Interval & Kategori \\
\hline $85-100$ & Sangat Tinggi \\
$71-85$ & Tinggi \\
$56-70$ & Sedang \\
$41-55$ & Rendah \\
\hline
\end{tabular}

(dalam Asmurni 2019) 


\section{HASIL DAN PEMBAHASAN}

Tindakan yang dilakukan dalam penelitian ini adalah penerapan model pembelajaran group investigation di mana masing-masing kelompok siswa diberikan masalah yang berbeda untuk dilakukan investigasi secara berkelompok sehingga menemukan pemahaman terhadap konsep atau prinsip yang sedang dilakukan investigasi. Topik yang dibahas oleh siswa adalah perilaku terpuji yang terbagi dalam subtopik meneladani perilaku Nabi Ayub AS, Nabi Musa AS, dan Nabi Isa AS. Selama proses pelaksanaan guru memberikan bimbingan terhadap pelaksanaan tindakan yang dilakukan guru, pelaksanaan ini dibantu oleh guru lain sebagai observer guna melihat aktifitas siswa sehingga dapat dijadikan bahan pertimbangan jika terjadi kendala dan memberikan masukan perbaikan untuk siklus berikutnya.

Siklus I

Pada siklus I, guru merancanakan pembelajaran PAI dengan membuat RPP yang dimodifikasi dengan model pembelajaran GI.
Siswa diberikan kesempatan untuk memilih topik yang akan dibahas bersama kelompok. Masingmasing kelompok merencanakan kerjasama dan melakukan kegiatan investigasi, selama proses berlangsung guru membantu siswa melakukan analisis dan sintesis dari penemuan siswa. Setelah data dikaji selanjutnya disajikan dalam laporan dan dinilai bersama siswa lain atas bimbingan guru dan evaluasi dilakukan oleh guru.

\section{Aktivitas Siswa}

Aktivitas pembelajaran dirancang sedemikian rupa agar pembelajaran yang dilaksanakan siswa sesuai dengan model pembelajaran GI. Aktifitas siswa diobservasi untuk melihat implementasi model pembelajaran GI diterapkan. Sehingga jika terjadi kekurangan atau kendala di lapangan dapat dievaluasi untuk dilakukan perbaikan agar mencapai kriteria yang diharapkan oleh peneliti.

Adapun hasil aktifitas siswa pada siklus I dapat dilihat pada tabel berikut:

Tabel 4. Aktivitas Siswa dalam Proses Model Pembelajaran Group Investigation

\begin{tabular}{ccc}
\hline Fase & Skor & Kategori \\
\hline Seleksi Topik & $68 \%$ & Baik \\
Merencanakan Kerja Sama & $57 \%$ & Cukup \\
Implementasi & $55 \%$ & Cukup \\
Analisis dan Sintesis & $49 \%$ & Kurang \\
Penyajian Hasil Akhir & $56 \%$ & Cukup \\
Evaluasi & $60 \%$ & Cukup \\
\hline Keterangan & $\mathbf{5 7 , 5 \%}$ & Cukup \\
\hline
\end{tabular}

Berdasarkan data aktivitas siswa pada tabel 4 tersebut dapat dilihat bahwa skor aktivitas siswa dalam menerapkan model pembelajaran GI adalah sebesar $57.5 \%$ yang termasuk kategori cukup dengan fase terendah adalah analisis dan fase tertinggi adalah seleksi topik. Hal ini dikarenakan siswa belum terbiasa melakukan kegiatan belajar terutama menganalisis dan mensintesis penemuan. Oleh sebab itu, kemampuan siswa masih kurang dalam mengolah informasi yang diperoleh. Namun demikian, melalui model pembelajaran kooperatif model GI ini, aktivitas siswa sudah terlihat baik meskipun hanya beberapa siswa saja yang terlibat dalam proses pembelajaran. Merujuk pada catatan observasi bahwa hanya satu dua orang saja dalam masing-masing kelompok yang berperan aktif. Mengacu pada perihal tersebut, maka peneliti lebih menyiapkan siswa untuk terlibat aktif secara menyeluruh dengan meminta setiap siswa memiliki peran masing-masing dalam kelompoknya sehingga tidak ada siswa yang hanya sekedar duduk manis dalam kelompok. Pada fase evaluasi guru memberikan masukan agar siswa memahami petunjuk dalam melaksanakan kerja kelompok serta aktif bertanya jika terdapat kendala dalam pelaksanaan investigasi maupun pengolahan data dan 
informasi yang diperoleh selama implementasi kegiatan berlangsung.

Hasil Belajar Siswa

Hasil belajar siswa setelah diterapkan model pembelajaran GI cukup baik jika dibandingkan dengan pemahaman awal siswa. Persentase siswa yang tuntas dan skor rata-rata tes UH masih di bawah KKM yang ditetapkan. Untuk lebih jelas data hasil belajar siswa berdasarkan UH I dapat dilihat pada tabel berikut:

Tabel 5. Hasil Belajar Siswa pada Data Awal dan UH I

\begin{tabular}{cccccc}
\hline \multirow{2}{*}{ Siklus } & \multirow{2}{*}{ Jumlah Siswa } & \multicolumn{2}{c}{ Ketuntasan Klasikal } & \multicolumn{2}{c}{ Rata-rata Hasil Belajar } \\
& & Tuntas & Persentase & Interval & Kategori \\
\hline Data awal & 30 & 11 & $36,7 \%$ & 61,1 & Sedang \\
Siklus I (UH I) & 30 & 17 & $56,7 \%$ & 64,5 & Sedang \\
\hline
\end{tabular}

Berdasarkan tabel 5 tersebut, dapat dilihat bahwa terjadi peningkatan ketuntasan individu sebesar $20 \%$ dari 11 siswa menjadi 17 siswa pada siklus I dengan nilai rata-rata hasil belajar siswa dari 61.1 yang termasuk pada kategori sedang meningkat menjadi 64.5 yang termasuk dalam kategori sedang. Peningkatan ini terjadi karena siswa menemukan sendiri solusi dari permasalahan yang disajikan guru melalui pembelajaran investigasi. Hal ini senada dengan penelitian yang dilakukan oleh Efendi \& Koto (2015) bahwa perencanaan dan pelaksanaan pembelajaran model GI dapat meningkatkan efektivitas pembelajaran fisika siswa jika ditinjau dari capaian daya serap dan ketuntasan belajar klasikal.

\section{Refleksi}

Mengacu pada aktivitas siswa yang cukup dan hasil belajar siswa yang sedang, maka hasil ini belum mencapai kriteria ketuntasan yang diharapkan. Hal ini menjadi catatan penting untuk perbaikan di siklus selanjutnya di mana perbaikan yang dilakukan adalah memaksimalkan perlakuan pada fase implementasi, analisis dan sintesis, serta penyajian hasil akhir. Tindakan yang perlu dimaksimalkan adalah memberikan instruksi yang lebih jelas dari setiap rencana kegiatan, kemudian siswa dibimbing melakukan analisis dengan pertanyaan arahan, sehingga siswa mampu menyajikan hasil dengan lengkap dan akurat. Harapan dari maksimalnya perlakuan ini adalah meningkatnya hasil belajar PAI siswa pada UH II.

\section{Siklus II}

Pembelajaran pada siklus II mengacu pada perbaikan dari siklus I. Pada siklus II ini terlihat peningkatan baik dari segi aktivitas siswa maupun hasil belajar siswa. Hal ini mengisyaratkan bahwa penerapan model pembelajaran GI dapat terlaksana dengan baik dan sesuai dengan perencanaan yang disusun. Pelaksanaan sudah mulai optimal karena guru meyiapkan pelajaran sesuai dengan kebutuhan siswa serta mencari solusi atas kebutuhan tersebut.

\section{Aktivitas Siswa}

Untuk melibatkan siswa agar aktif dalam proses pembelajaran, maka guru mewajibkan setiap siswa dalam kelompok memiliki peran masing-masing, seperti menulis temuan dan jawaban, mencari data dan informasi, melakukan kegiatan investigasi, dan sebagainya sehingga dengan demikian keterlibatan siswa dalam proses pembelajaran akan meningkat dan semakin baik. Kerja sama antarkelompok menumbuhkan rasa tanggung jawab dan meningkatkan pemahaman secara utuh terhadap investigasi yang dilakukan. Adapun hasil aktivitas siswa pada siklus I dapat dilihat pada tabel berikut: 
Tabel 6. Aktifitas Siswa dalam Proses Model Pembelajaran Group Investigation

\begin{tabular}{ccc}
\hline Fase & Skor & Kategori \\
\hline Seleksi Topik & $82 \%$ & Tinggi \\
Merencanakan Kerja Sama & $77 \%$ & Tinggi \\
Implementasi & $68 \%$ & Sedang \\
Analisis dan Sintesis & $59 \%$ & Sedang \\
Penyajian Hasil Akhir & $75 \%$ & Tinggi \\
Evaluasi & $74 \%$ & Tinggi \\
\hline Keterangan & $\mathbf{7 2 , 5 \%}$ & Tinggi \\
\hline
\end{tabular}

Tabel 6 menujukkan terjadinya peningkatan yang signifikan terhadap aktivitas siswa dalam proses pembelajaran model GI dengan persentase sebesar 72.5 yang termasuk kategori tinggi. Hal ini terjadi karena pada seleksi topik siswa tidak lagi secara rebutan dengan kelompok lain melainkan masing-masing siswa melakukan cabut undi di mana setiap nomor sudah ditetapkan topik yang hendak dibahas oleh kelompok yang mendapatkan nomor tertentu. Pada fase perencanaan kerja sama, masingmasing siswa sudah memiliki peran dan fungsi masing-masing dalam kelompok sehingga perencanaan terlihat lebih tersusun. Pada fase implementasi masing-masing siswa sudah memahami peran masing-masing sehingga setiap siswa fokus pada tugas masing-masing apabila terdapat kendala maka akan langsung ditanyakan pada rekan lain maupun pada guru sehingga kendala yang dihadapi dapat diselesaikan dengan baik, hal ini juga meningkatkan keterampilan siswa dalam melakukan investigasi maupun eksperimen. Hal ini senada dengan Sutama (2007) dan Azizah, dkk (2012) bahwa kemampuan dan kreatifitas mahasiswa meningkat dengan penerapan model pembelajaran GI. Pada fase analisis dan sisntesis masih menjadi indikator terendah namun sudah mengalami peningkatan yang lebih baik karena guru telah menyiapkan pertanyaan arahan untuk menemukan jawaban terhadap masalah yang disajikan. Pada fase penyajian hasil akhir setiap kelompok sudah mampu menyimpulkan permasalahan yang dihadapi dengan baik. Pada fase evaluasi guru dan siswa sama-sama mereview proses dan kesimpulan yang diajukan sehingga kesimpulan akhir akan sama antara guru dan siswa dan tidak terjadi kesalahpahaman terhadap konsep dan teori yang dipelajari.

\section{Hasil Belajar Siswa}

Hasil belajar siswa setelah dilakukan perbaikan pada siklus I berdasarkan catatan dan saran hasil observasi mengalami peningkatan. Persentase siswa yang tuntas dan skor rata-rata tes UH sudah mencapai KKM yang ditetapkan. Untuk lebih jelas data hasil belajar siswa berdasarkan UH II dapat dilihat pada tabel berikut

Tabel 7. Hasil Belajar Siswa pada Data Awal, UH I dan UH II

\begin{tabular}{cccccc}
\hline Siklus & $\begin{array}{c}\text { Jumlah } \\
\text { Siswa }\end{array}$ & $\begin{array}{c}\text { Ketuntasan Klasikal } \\
\text { Tuntas }\end{array}$ & $\begin{array}{c}\text { Rersentase } \\
\text { Rata-rata Hasil Belajar } \\
\text { Interval }\end{array}$ & Kategori \\
\hline Data awal & 30 & 11 & $36,7 \%$ & 61,1 & Sedang \\
Siklus I (UH I) & 30 & 17 & $56,7 \%$ & 64,5 & Sedang \\
Siklus II (UH II) & 30 & 24 & $80 \%$ & 75,3 & Tinggi \\
\hline
\end{tabular}

Berdasarkan hasil UH II yang disajikan pada tabel 7 tersebut terlihat bahwa sebanyak 24 siswa atau sebesar $80 \%$ siswa sudah memenuhi KKM yang ditetapkan dengan rata-rata hasil belajar siswa sebesar 75.3 yang termasuk dalam kategori tinggi. Peningkatan ketuntasan klasikal siklus II dari siklus I terjadi sebesar 23.3\%. Hal ini menunjukkan bahwa model pembelajaran GI dapat meningkatkan hasil belajar siswa pada mata pelajaran PAI.

Peningkatan aktifitas dan hasil belajar siswa ini senada dengan penelitian Indrawati (2018) bahwa penerapan pembelajaran kooperatif tipe Group Investigation (GI) efektif dalam meningkatkan hasil belajar siswa. Berdasarkan hasil tersebut maka penelitian ini dianggap berhasil dan tidak perlu dilanjutkan pada siklus selanjutnya. 


\section{SIMPULAN DAN REKOMENDASI}

Berdasarkan hasil dan pembahasan yang dikemukakan dapat ditarik kesimpulan bahwa aktivitas siswa menujukkan peningkatan yang signifikan dari siklus I sebesar $57.5 \%$ dengan kategori cukup menjadi $72.5 \%$ yang termasuk kategori tinggi. Hal ini menunjukkan keterlibatan siswa dalam penerapan model pembelajaran GI sesuai dengan perencanaan yang diharapkan peneliti. Hasil belajar siswa memenuhi kriteria ketuntasan yang ditetapkan dimana sebanyak 24 siswa atau sebesar $80 \%$ telah memenuhi KKM dengan rata-rata hasil belajar adalah sebesar 75.3 yang termasuk dalam kategori tinggi.

Rekomendasi berdasarkan fakta dan

\section{DAFTAR PUSTAKA}

$\begin{array}{ccr}\text { Asmurni. (2019). } \begin{array}{c}\text { Keefektifan } \\ \text { Pembelajaran }\end{array} \text { Kontruktivisme } & \begin{array}{r}\text { dalam } \\ \text { Meningkatkan Hasil Belajar IPA }\end{array} & \text { Siswa } \\ \text { Kelas VI SD Negeri 003 Benai } & \text { Kecil. } \\ \text { Jurnal PAJAR (Pendidikan } & \text { dan } \\ \text { Pengajaran), 3 (5), 995-1002. } & \end{array}$

Asrawati. (2019). Implementasi Pembelajaran Kooperatif Tipe Snowball Throwing untuk Meningkatkan Hasil Belajar IPA Siswa Kelas II SD Negeri 007 Kampung Baru Kecamatan Gunung Toar. Jurnal PAJAR (Pendidikan dan Pengajaran), 3(2), 327333.

Azizah, M., Rustiana, A., dan Pramusinto, H. (2012). Penerapan Model Pembelajaran Group Investigation untuk Meningkatkan Kreativitas Siswa pada Pelajaran Produktif. Economic Education Analysis Journal, 1 (1), 1-7.

Dasinah. (2019). Keefektifan Model Pembelajaran Group Investigation pada Mata Pelajaran IPA Kelas VI SDN 016 Marsawa. Jurnal PAJAR (Pendidikan dan Pengajaran), 3(3), 615-622.

Efendi, S., dan Koto, I. (2015). Perencanaan dan Pelaksanaan Pembelajaran Koperatif Tipe Investigasi Kelompok untuk Meningkatkan Efektivitas Pembelajaran Fisika Kelas X: Penelitian Tindakan Kelas. Jurnal Penelitian \& Pengembangan Pendidikan Fisika, 1 (1), 39-46. kesimpulan adalah agar peneliti selanjutnya berupaya memahami permasalahan siswa yang berkaitan dengan lingkungan sehari-hari siswa, dari itu perencanaan dapat dimaksimalkan mengacu pada kebutuhan siswa, kemudian peneliti harus memberikan petunjuk yang jelas dalam setiap tindakan baik dengan instruksi maupun dengan pertanyaan arahan, setiap kelompok harus dibimbing agar tidak terjadi vakum maupun kekeliruan dalam pelaksanaan tindakan, peneliti harus bekerja sama dengan observer agar perbaikan yang dibutuhkan siswa dapat dimaksimalkan dengan baik.

Hasnawati. (2019). Penerapan Model Pembelajaran Picture and Picture untuk Meningkatkan Hasil Belajar IPA Siswa Kelas II A SD Negeri 004 Cendirejo Kecamatan Pasir Penyu Kabupaten Indragiri Hulu. Jurnal PAJAR (Pendidikan dan Pengajaran), 3 (1), 189-196.

Hosnan (2014). Pendekatan Saintifik dan Kontekstual dalam Pembelajaran Abad 21. Bogor: Ghalia Indonesia.

Indrawati. (2018). Pembelajaran Group Investigasi Meningkatkan Hasil Belajar Siswa. Jekpend Jurnal Ekonomi Dan Pendidikan, 1 (1) 17-26.

Marhadi, H., dan Erlisnawati. (2016). Peningkatan Hasil Belajar Mahasiswa pada Mata Kuliah Manajemen Kelas dengan Penerapan Model Pembelajaran Kooperatif Tipe Group Investigation Program Studi Pendidikan Guru Sekolah Dasar Universitas Riau. Primary: Jurnal Pendidikan Guru Sekolah Dasar, 5 (1), 1-13.

Rosdianah. (2019). Penerapan Model Pembelajaran Kooperatif Tipe Three Stay One Stray (TSOS) untuk Meningkatkan Hasil Belajar IPA Siswa Kelas IV SD Negeri 023 Pulau Kijang Kecamatan Reteh. Jurnal PAJAR (Pendidikan dan Pengajaran), 3 (2), 360-368.

Suroyya, D, N., dan Rochmad. (2015). Studi Komparasi Pembelajaran Novick dan 
Jurnal PAJAR (Pendidikan dan Pengajaran)

Volume 3 Nomor 6 November 2019 |ISSN Cetak : 2580 - 8435| |ISSN Online : 2614 - 1337

DOI : http://dx.doi.org/10.33578/pjr.v3i6.7900

Group Investigation Terhadap Kemampuan Spasial Siswa Kelas VIII Materi Geometri. Unnes Journal of Mathematics Education, 4 (1), 95-102.

Sutama. (2007). Model Pembelajaran Kooperatif Group Investigation untuk Pengembangan Kreativitas Mahasiswa. Jurnal Varidika, 19 (1). 